\title{
Landscape dynamics and its impacts in the Atlantic Forest area of Southeastern Brazil
}

\author{
Mayara Maria de Lima Pessoa ${ }^{1}\left[\right.$, Daniel Costa de Carvalho² ${ }^{\circledR}$,

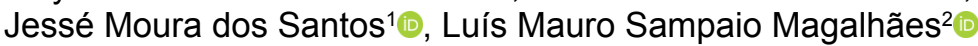

\footnotetext{
1 Universidade Federal Rural de Pernambuco, Recife-PE, Brazil. E-mail: maypessoa@gmail.com; jessemourajm@gmail.com

2 Universidade Federal Rural do Rio de Janeiro, Seropédica-RJ, Brazil. E-mail: danielcostadecarvalho@gmail.com; I.mauro@terra.com.br
}

ABSTRACT: The objective of this study was to evaluate the spatial-temporal dynamics of land-use and coverage in the Parque Estadual da Pedra Selada (PEPS) and its landscape, located in Resende and Itatiaia, Rio de Janeiro. Orbital images of the Landsat platform were obtained for the years 1985, 1995, 2005 and 2015. NDVI was calculated for each year, and its amplitude described the classes of land-use and coverage in water bodies, urban area, exposed soil, grassland and forest. For landscape analysis, a 3-km radius buffer was incorporated, delimiting the Buffer Zone (BZ). The forest class was the largest in all years, but there was a reduction in its area over time, especially in BZ. An increase was observed in the grassland and urban areas when comparing the years 1995 and 2015, where the urban area doubled its territory. Intense anthropic activity explains this transition as livestock activities began to be used for urban sprawl. The increase in deforested areas in the region, due to pressures such as tourism, real estate speculation, farming and agriculture, drives the fragmentation process that may affect the diversity of flora and fauna present in PEPS.

Key words: buffer zone; land use and cover; protected area

\section{Dinâmica da paisagem e seus impactos na Floresta Atlântica no Sudeste do Brasil}

RESUMO: O objetivo deste estudo foi avaliar a dinâmica espaço-temporal do uso e cobertura da terra no Parque Estadual da Pedra Selada (PEPS), e sua paisagem, localizada em Resende e Itatiaia, no Rio de Janeiro. Imagens orbitais da plataforma Landsat foram obtidas para os anos de 1985, 1995, 2005 e 2015. O NDVI foi calculado para cada ano, e sua amplitude descreveu as classes de uso e cobertura da terra em corpos de água, área urbana, solo exposto, pastagem e Floresta. Para análise da paisagem, um buffer com raio de $3 \mathrm{~km}$ foi incorporado delimitando a Zona de Amortecimento (ZA). A classe Floresta foi a maior classe em todos os anos, mas houve uma redução em sua área ao longo do tempo, principalmente na ZA. Observou-se um aumento nas pastagens e áreas urbanas quando comparados os de 1995 e 2015, onde a área urbana dobrou sua área. A intensa atividade antrópica explica essa transição à medida que as atividades pecuárias começaram a ser utilizadas para a expansão urbana. $O$ aumento das áreas desmatadas na região, devido a pressões como turismo, especulação imobiliária, agricultura e agricultura, impulsiona o processo de fragmentação que pode afetar a diversidade de flora e fauna presentes no PEPS.

Palavras-chave: zona de amortecimento; uso e cobertura do solo; área protegida 


\section{Introduction}

Protected areas are one of the pillars in conserving the biodiversity of tropical forests remnants (Defries et al., 2005). In the entire world, creation of these areas was significantly increased in the last 30 years (Robinson et al., 2013), due to processes of perturbation and degradation, mainly of anthropic nature (Nguyen et al., 2018). In Brazil, Conservation Units (CUs) exist since 1937 with the creation of the Itatiaia National Park, which aimed at maintaining natural resources for the benefit of current and future generations (Barreto et al., 2013).

However, several regions have suffered environmental impacts where CUs are currently established, which includes adjacent areas. For Dalla Nora \& Santos (2011), only the creation and delimitation of CUs are not able to ensure the conservation and maintenance of ecological functions and protection of biodiversity, but it is also necessary to understand its surroundings. According to the National System of Conservation Units (NSCU), the surroundings of CUs are called buffer zones (BZ), where anthropic activities are subject to specific norms and constraints of each region, to minimize the negative impacts on the CU (Brasil, 2000).

Thereby, it is evident the need of studies related to the monitoring of land-use patterns both in CUs and in delicate and threatened regions such as the Atlantic Forest, including also the research on the modifications in the BZs, and thus representing the landscape. In this context, CUs of Integral Protection (Brasil, 2000), such as the Parque Estadual da Pedra Selada (PEPS), presents potential for research related to the monitoring of land-use and land cover in the Atlantic Forest. Moreover, due to the history of use and occupation, throughout the time, it also presents a fragmented landscape, as well as several Atlantic Forest phytophysiognomies in different successional stages (Detzel Consulting, 2017).

Before the creation of PEPS, its areas and the environment suffered environmental impacts mainly because of agricultural use. Deforestation also compromised the conservation of natural resources, and there is a need for studies that can understand how the anthropic activities altered the landscape in order to understand the relations between its transformation and society. However, to evaluate the landscape dynamics of PEPS, it is essential to integrate tools capable of detecting and quantifying changes in the region (Carvalho et al., 2016).

Multitemporal data, through remote sensing, can be used in evaluating the patterns of land-use changes, as well as its degradation levels (Crouzeilles et al., 2013; Ferraz et al., 2014; Rosa et al., 2017). Other authors also discuss the role of remote sensing in the vegetation dynamics, whether at local, regional or global scales (Dalla Nora \& Santos, 2011; Hansen \& Loveland, 2012; Nguyen et al., 2018). Remote sensing is also a valuable tool that helps to comprehend the forest fragmentation. For Rosa et al. (2017), as a consequence of the Atlantic Forest fragmentation, through knowledge of the temporal dynamics of the vegetation, it is possible to identify patterns, processes, and mechanisms that can be used to predict and guide strategies for rational use, protection and conservation of forest resources. Furthermore, Dalla Nora \& Santos (2011), when analyzing the use activities around CUs in Atlantic Forest, identified elements that question functionality, as well as contradictions in the limits and sustainable development.

Therefore, this research was based on the hypothesis that there were significant changes in the local landscape, even after the PEPS creation. In addition, this paper intends to answer the following questions: How did the change in landuse and land cover occur before and after the PEPS creation? Currently, what are the main threats that can interfere in the conservation of the study area, beyond the PEPS limits? Hence, this research aims to evaluate the space-time dynamics (from 1985 to 2015) of land-use and land cover in PEPS and its landscape.

\section{Material and Methods}

The study was conducted at Parque Estadual da Pedra Selada - PEPS located between the coordinates: North Bagagem District, in the municipality of Resende, near

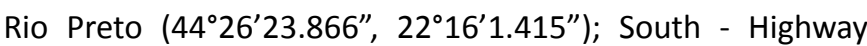
BR-116 Presidente Dutra, in the municipality of Itatiaia (443'ㅇ․ $\left.464^{\prime \prime}, 22^{\circ} 28^{\prime} 56.289^{\prime \prime}\right)$ (Figure 1). This Integral Protection Conservation Unit is part of the Environmental Protection Area of Serra da Mantiqueira (Rio de Janeiro, 2012) along with the Itatiaia National Park (INP). PEPS has a total area of 8.036 hectares, and the BZ corresponds to approximately 41.237 hectares, mostly in the municipality of Resende and a small part (about $5 \%$ ) in the municipality of Itatiaia (Rio de Janeiro, 2012) (Figure 1).

Orbital images from Landsat 5 sensor TM (Thematic Mapper) and Landsat 8 OLI sensor used in this study were

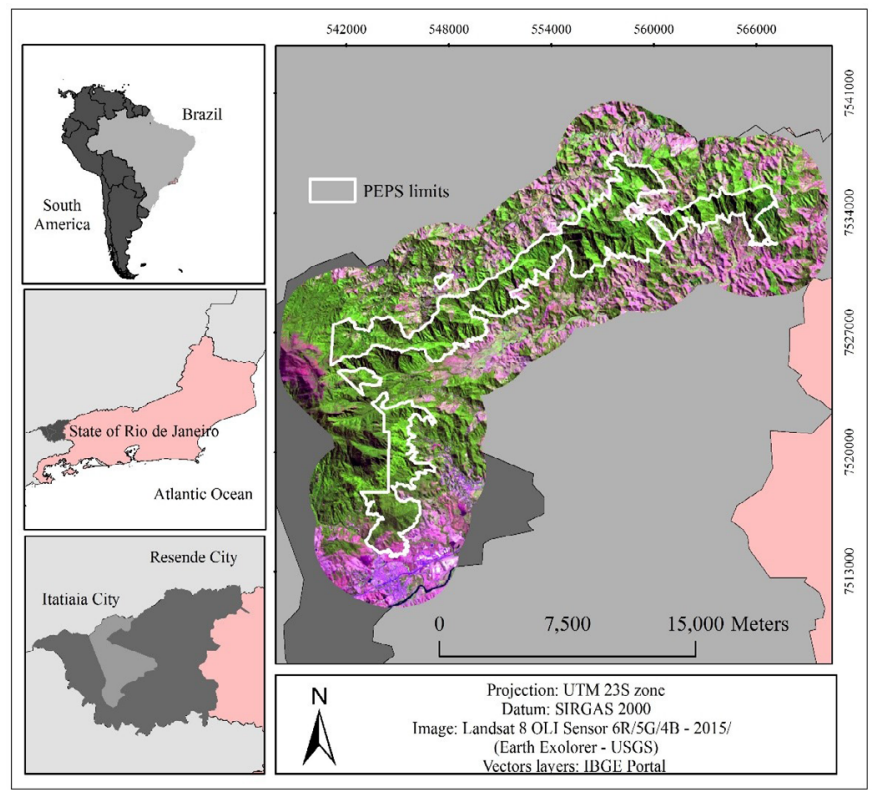

Figure 1. Location of the Parque Estadual da Pedra Selada (PEPS) and its Buffer Zone (BZ), RJ, Brazil. 
purchased for free in the electronic image catalog of the National Institute of Meteorology of Space Research (http:// www.dgi.inpe.br/ CDSR/). The years considered for this study were 1985, 1995, 2005, and 2015 (Table 1).

After the acquisition of the images with Thematic Mapper (TM) sensor, steps of radiometric calibration and reflectivity were performed according to the method proposed by Chander et al. (2007) using the algorithms of the SEBAL (Surface Energy Balance Algorithm for Land), proposed by Bastiaanssen (1995). After the correction steps of the images, they were processed again to calculate the Normalized Difference Vegetation Index (NDVI) proposed by Rouse et al. (2006), with their respective amplitude values (Table 2). This index is obtained from the spectral information contained in the red and infrared bands near TM-Landsat 5 (Bands 3 and 4) and OLI-Landsat 8 (Bands 4 and 5) (Equation 1).

$$
\mathrm{NDVI}=\frac{\mathrm{NIR}-\mathrm{RED}}{\mathrm{NIR}+\mathrm{RED}}
$$

where: NDVI - Index of Vegetation of Normalized Difference; NIR - Near Infrared; RED - Red. It varies from -1 to +1 , where usually surfaces with some vegetation should have values between 0 and 1, and for surfaces such as water and clouds, the value should generally be less than zero.

For the analysis of land-use and coverage, the images were subjected to the Maximum Likelihood supervised classification, and the Kappa coefficient performed the reliability aided by QGIS 2.18 and the complement "SemiAutomatic Classification Plugin - SCP" (QGIS Development Team, 2018).

In the process of discrimination and nomenclature of land-use and land cover classes, water, urban area, soil exposure, pasture, and forest were used for this study (IBGE, 2013) (Table 2). A "forest" class comprises forests in various locations - such as Dense Montane and Submontane Dense Ombrophilous Forests present in the study region.

Due to the best clustering, regarding the spectral response of the targets, the Natural Breaks algorithm (Jenks) was used in ArcGIS 10.2 (Esri, 2009) to divide the data into five reflectance intervals. This method is based on grouping similar values, maximizing and facilitating the separability between classes. Moreover, in agreement with some authors (Franco \& Rosa, 2004; Lima et al., 2013; Maranhão et al., 2017; Torres et al., 2019) in studies conducted in Southeastern Brazil, which consider NDVI as an efficient tool for reflectance intensity in different targets, mainly for vegetation, it was possible to assume the values (Table 2 ) presented in this research.
Table 2. NDVI amplitude for land-use and coverage classes of the Parque Estadual da Pedra Selada, Rio de Janeiro State (Brazil).

\begin{tabular}{ccc}
\hline \multirow{2}{*}{ Classes } & \multicolumn{2}{c}{ NDVI amplitude } \\
\cline { 2 - 3 } & Minimum & Maximum \\
\hline Water & -0.455 & 0.18 \\
Urban area & 0.181 & 0.322 \\
Exposed soil & 0.323 & 0.448 \\
Grassland & 0.449 & 0.566 \\
Forest & 0.567 & 0.754 \\
\hline
\end{tabular}

The field validation was performed in October 2015, the last year of the spatial-temporal analysis. Twenty control points were collected for each NDVI class, before the on-site check, observing aspects of the forest physiognomy, as well as the grassland areas.

In order to analyze the landscape dynamics, a $3-\mathrm{km}$ radius buffer with was defined at the PEPS boundary, delimiting the buffer zone (Figure 1). This procedure was adopted to understand, in the landscape context, the changes in land-use and land cover that occurred in the PEPS Buffer Zone in the analyzed years.

Mathematical operations in GIS environment were applied in the four registration maps to obtain the changes of landuse and coverage in 1985, 1995, 2005 and 2015, following the methodology of Moraes et al. (2016). The amount of area, in hectares, the percentage in the buffer zone, and the percentage values of variations (conversions) between the spans 1985-2015, 2005-2015, and 1985-2015 were obtained for each class of land-use and coverage for each year studied.

It was also calculated the difference of the class areas (hectares) between the studied years, to verify the increase or decrease of a given class in the PEPS and into the BZ, based on the following Equation 2.

$$
\text { Difference }=\text { initial year area }- \text { final year area }
$$

Thus, the percentage of change for each period was calculated using the following Equation 3.

Change $($ class $)(\%)=\frac{(\text { final area of the year }- \text { initial area of the year })}{\text { initial area }} \times 100$

In general, negative results of Equation 2 meant that a particular class decreased its areas, while positive values correspond to an increase in the class. A value of " $0 \%$ " indicates that the class remained stable over the years.

Through the combination of all land-use and cover maps, the results were displayed in another map showing the

Table 1. Characteristics of the images obtained for the mapping of land-use and coverage in Parque Estadual da Pedra Selada and its buffer zone (BZ), RJ, Brazil.

\begin{tabular}{ccccc}
\hline Satellite/Sensor & Point & Orbit & Date & NDVI Band \\
\hline Landsat 5/TM & 217 & 75 & $09 / 06 / 1985$ & $3 R, 4 N I R$ \\
Landsat 5/TM & 217 & 75 & $24 / 07 / 1995$ & $3 R, 4 N I R$ \\
Landsat 5/TM & 217 & 75 & $03 / 07 / 2005$ & $3 R, 4 N I R$ \\
Landsat 8/OLI & 217 & 75 & $05 / 08 / 2015$ & $4 R, 5 N I R$ \\
\hline
\end{tabular}


changes in 1985, 1995, 2005 and 2015. The discussion and understanding of the changes were based on the literature, reports of older residents, and the PEPS managers.

\section{Results and Discussion}

The results of the mapping showed that during the analyzed period of twenty years (1985-2015), there were changes in the forest cover of the PEPS and its landscape, mainly in what corresponded to the BZ (Table 3). Overall, the class accuracy by the Kappa index was considered as very good (Table 4), indicating that the control points validated the classification prepared by the Maximum Likelihood supervised classification method. In the PEPS, between 1985 and 1995, there was an increase in urban area (+56.04 ha, $+0.7 \%)$, exposed soil (+93.14 ha, $+11.7 \%)$, and grassland (+114.88 ha, $+1.6 \%$ ) (Table 4$)$. In the $B Z$, there was a decrease in urbanized areas $(-420.33$ ha, $-1.19 \%)$, and for grassland $(-2125.41 \mathrm{ha},-5.85 \%)$ and the areas of exposed soil increased $(+2518.88$ ha, $+8.36 \%)$. Between 1995 and 2005, there was an increase in grassland for both PEPS (+345.02 ha; +4.29\%) and BZ (+2562.80 ha; +7.71\%) (Table 4). Between 2005 and 2015, in PEPS areas there was a decrease in exposed soil (-93 ha; $-1.16 \%$ ) and grassland (-669.53 ha; $-8.33 \%)$, and in BZ areas there was an increase of urban areas (+1217.27 ha) and in the grassland (+2562.91 ha, $+7.72 \%$ ), corresponding to grassland (Table 5).

Within the PEPS limits, the forest class was the largest in all evaluated years (Table 4, Figure 2a), representing values above

Table 3. Total area, in hectares, of the classes of land-use and coverage, observed in the Parque Estadual da Pedra Selada (PEPS) and the buffer zone (BZ), RJ.

\begin{tabular}{|c|c|c|c|c|c|c|c|c|}
\hline \multirow{3}{*}{ Classes } & \multicolumn{2}{|c|}{1985} & \multicolumn{2}{|c|}{1995} & \multicolumn{2}{|c|}{2005} & \multicolumn{2}{|c|}{2015} \\
\hline & \multicolumn{8}{|c|}{$\mathrm{Ha}$} \\
\hline & PEPS & $\mathrm{BZ}$ & PEPS & BZ & PEPS & BZ & PEPS & BZ \\
\hline Water & 1.27 & 97.55 & 51.04 & 262.16 & 0.00 & 28.44 & 0.00 & 32.04 \\
\hline Urban area & 6.34 & 669.89 & 62.38 & 249.56 & 2.85 & 492.01 & 19.71 & 1709.28 \\
\hline Exposed soil & 255.08 & 6710.70 & 1186.48 & 9229.58 & 189.30 & 7163.66 & 96.30 & 3706.83 \\
\hline Grassland & 397.10 & 4768.56 & 511.98 & 2643.15 & 857.00 & 5205.95 & 187.47 & 8071.83 \\
\hline Forest & 7659.48 & 22288.52 & 6223.56 & 20825.49 & 6987.27 & 20311.46 & 7733.88 & 19647.81 \\
\hline Totals & 8319.26 & 34535.21 & 8035.44 & 33209.94 & 8036.42 & 33201.53 & 8037.36 & 33167.79 \\
\hline
\end{tabular}

Table 4. Percentage, and Kappa hat classification of the classes of land-use and coverage, observed in the buffer zone (BZ) in Parque Estadual da Pedra Selada (BF + PEPS), RJ.

\begin{tabular}{|c|c|c|c|c|c|c|c|c|c|c|c|c|}
\hline \multirow{3}{*}{ Classes } & \multicolumn{3}{|c|}{1985} & \multicolumn{3}{|c|}{1995} & \multicolumn{3}{|c|}{2005} & \multicolumn{3}{|c|}{2015} \\
\hline & \multicolumn{12}{|c|}{$\%$} \\
\hline & PEPS & $\mathrm{BZ}$ & Kappa & PEPS & $B Z$ & Kappa & PEPS & BZ & Kappa & PEPS & BZ & Kappa \\
\hline Water & 0.02 & 0.28 & 100.00 & 0.64 & 0.79 & 100.00 & 0.00 & 0.09 & 100.00 & 0.00 & 0.10 & 100.00 \\
\hline Urban area & 0.08 & 1.94 & 94.06 & 0.78 & 0.75 & 89.64 & 0.04 & 1.48 & 86.18 & 0.25 & 5.15 & 82.10 \\
\hline Exposed soil & 3.07 & 19.43 & 81.66 & 14.77 & 27.79 & 68.07 & 2.36 & 21.58 & 58.07 & 1.20 & 11.18 & 61.87 \\
\hline Grassland & 4.77 & 13.81 & 57.63 & 6.37 & 7.96 & 61.08 & 10.66 & 15.68 & 63.43 & 2.33 & 24.34 & 49.80 \\
\hline Forest & 92.07 & 64.54 & 79.94 & 77.45 & 62.71 & 82.96 & 86.95 & 61.18 & 84.69 & 96.22 & 59.24 & 84.94 \\
\hline $\begin{array}{c}\text { Kappa hat } \\
\text { classification }\end{array}$ & & & 82.65 & & & 80.35 & & & 78.47 & & & 75.74 \\
\hline
\end{tabular}

Table 5. Additions and losses of the land-use and coverage in the Buffer Zone and in the PEPS, for the periods of 1985-1995, 1995-2005, 2005-2015 and 1985-2015.

\begin{tabular}{|c|c|c|c|c|c|c|c|c|}
\hline \multirow{3}{*}{ Classes } & \multicolumn{2}{|c|}{$1985-1995$} & \multicolumn{2}{|c|}{$1995-2005$} & \multicolumn{2}{|c|}{ 2005-2015 } & \multicolumn{2}{|c|}{$1985-2015$} \\
\hline & \multicolumn{8}{|c|}{$\mathrm{Ha}$} \\
\hline & PEPS & BZ & PEPS & BZ & PEPS & $B Z$ & PEPS & BZ \\
\hline Water & - & - & - & - & - & - & - & - \\
\hline Urban area & +56.04 & -420.33 & -59.50 & +242.45 & +16.86 & +1217.27 & +13.47 & +1039.39 \\
\hline Exposed soil & +93.14 & +2518.88 & -997.18 & -2065.92 & -93.01 & -3456.83 & -158.78 & -3003.87 \\
\hline Grassland & +114.88 & -2125.41 & +345.02 & +2562.80 & -669.53 & +2865.88 & -209.63 & +3303.27 \\
\hline \multirow[t]{4}{*}{ Forest } & -1435.92 & -1463.03 & +763.71 & -514.03 & +746.61 & -514.03 & +744.01 & -2640.71 \\
\hline & \multicolumn{2}{|c|}{$1985-1995$} & \multicolumn{2}{|c|}{$1995-2005$} & \multicolumn{2}{|c|}{$2005-2015$} & \multicolumn{2}{|c|}{ 1985-2015 } \\
\hline & \multicolumn{8}{|c|}{$\%$} \\
\hline & PEPS & $B Z$ & PEPS & BZ & PEPS & $B Z$ & PEPS & BZ \\
\hline Water & - & - & - & - & - & - & - & - \\
\hline Urban area & 0.7 & -1.19 & -0.74 & 0.73 & 0.21 & 3.67 & 0.17 & 3.21 \\
\hline Exposed soil & 11.7 & 8.36 & 12.41 & -6.21 & -1.16 & -10.4 & -1.87 & -8.25 \\
\hline Grassland & 1.6 & -5.85 & 4.29 & 7.72 & -8.33 & 8.66 & -2.44 & 10.53 \\
\hline Forest & -14.62 & -1.83 & 9.5 & -1.53 & 9.27 & -1.94 & 4.15 & -5.3 \\
\hline
\end{tabular}



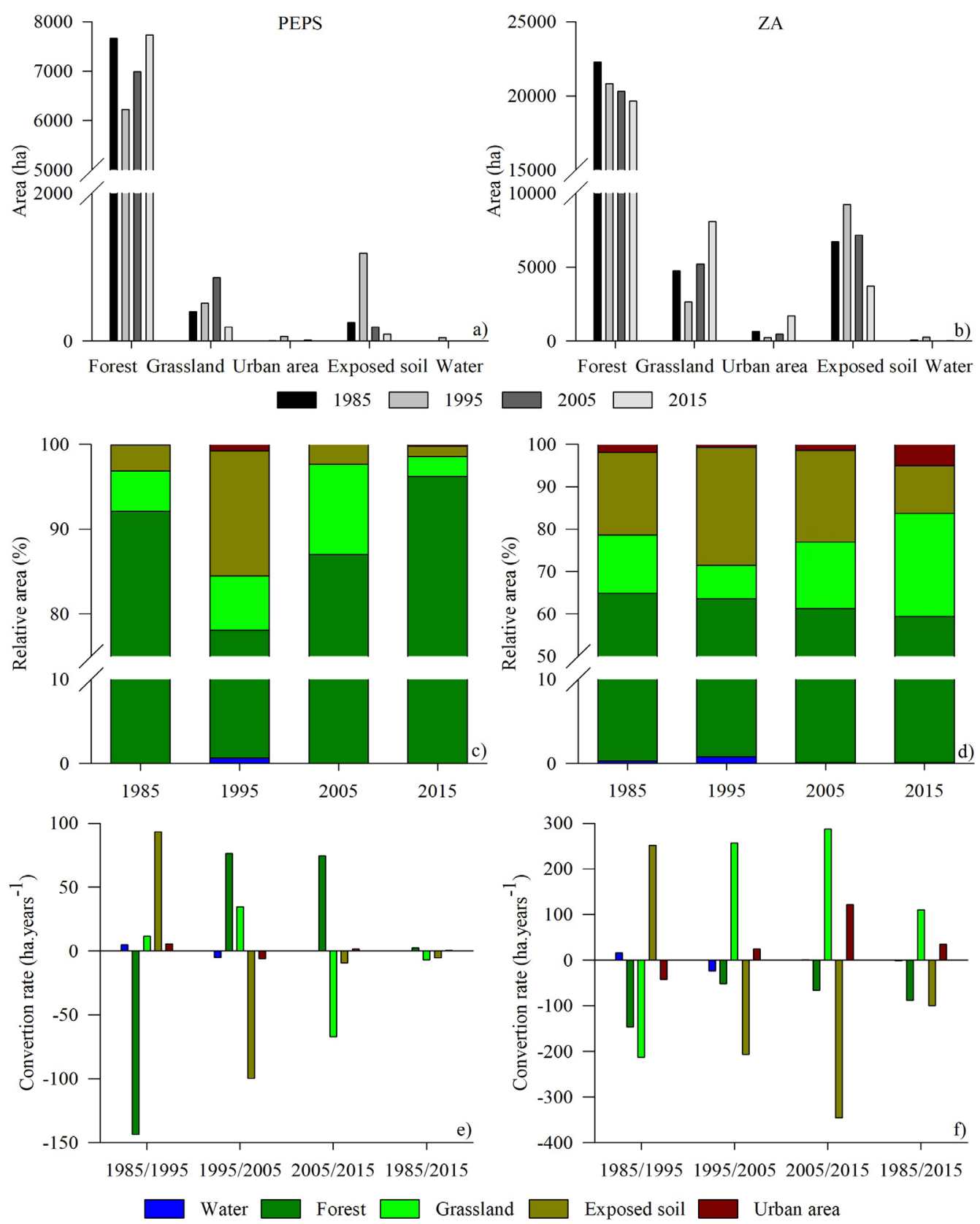

Figure 2. A, B) Class Area of land-use and coverage of the Buffer Zone and Parque Estadual da Pedra Selada; C, D) Relative area of land-use and coverage in the Buffer Zone and Parque Estadual da Pedra Selada; E, F) Conversion rate of land-use and coverage classes in the Buffer Zone and in Parque Estadual da Pedra Selada.

90\% in 1985 (Table 4), and with the decrease of its percentage in the interval between 1985 and 1995 (-14.64\%) (Table 5). In the other years, such areas increased again, where the forest areas represent $86.95 \%$ in 2005 and $96.22 \%$ in 2015 of the PEPS areas. In the BZ, the forest area decreased in all studied years, decreasing its representativeness in $5.3 \%$ between 1985 and 2015, while in 1985 the forest occupied $64.54 \%$ and it reduced to $62.71 \%, 61.18 \%$, and $59.24 \%$, respectively in 1995, 2005, and 2015 (Table 5).

According to the Ecological-Economic Zoning carried out in 2011 (Silva et al. 2010), the municipality of Resende stands out in the industrial and technological areas, and also has an extensive rural area that even today still has great potential, especially in primary production, with dairy farming and agriculture, as well as the services sector, such as ecotourism. This extensive rural area is characterized by the presence of grasslands, representing among the total extent of PEPS and its BZ, around 22,643.04 ha (52.84\% of its total area) in 2015.

For Souza \& Angelis (2011), when one CU is located in the rural area, as in this study, the challenges of conservation are mainly related to agricultural activities and predatory extractivism. These same authors also discuss that the presence of residents in the conservative units and its surrounds are one of the conservation challenges, where, historically, agricultural activities and human existence have always been constant, especially in the Buffer Zones. 
Although anthropic classes have vast areas around the PEPS, both the conversion of the forest and its recovery in the last decade of analysis (2005-2015), are probably due the effectiveness of instruments such as the Management Plan of the Serra da Mantiqueira Environmental Protected Area, an essential tool for territorial planning and management in the region. Detzel et al. (2018), comparing native forest vegetation found in intermediate and advanced stages of regeneration, showed that there was an increase of 19,338.80 ha, corresponding to about $3.55 \%$ of the total area of the Serra da Mantiqueira Environmental Protected Area. The authors related this gain to the evolution of early-stage forest formations in the early 1990s, mainly covering areas that were previously grassland or reforestation, as well as exposed soil.

On the other hand, the growth of visit number to the region has surpassed the support capacity of the tourist activity by the local and CU administrations (Dalla Nora \& Santos, 2011). As a result, it has been possible to note in several parts of the PEPS, especially in BZ, the consequences of tourism regarding the harmful use of space, which can lead to environmental degradation, pollution of water sources, garbage accumulation in inappropriate places, erosion processes, hunting and criminal collection of native vegetation, forest fires, among others. Furthermore, in regions such as Visconde de Mauá and Penedo, where the PEPS is located, the disorderly visitation of tourists ends up promoting real estate speculation and population densities in places where there were no buildings before (Detzel et al., 2017).
The exposed soil class is a result of inadequate practices linked mainly to agricultural activities and urbanization, as observed with the increase in urban area, mostly between 1995 and 2005. This factor is possibly due to the abandonment of agricultural land and pastures, which without management, consequently ended up as apparent soil (Detzel et al., 2018). Additionally, the process of urbanization generated in the vicinity of protected areas can become a problem for the conservation of CUs in Brazil and the world (Watson et al., 2013; Ahmad et al., 2013). Thus, the CUs have as challenges the control, inspection, and monitoring of changes in environmental and original characteristics that suffer threats mainly due the increase of urbanized areas.

The observed transition, with the advance of urban areas due the intense anthropic activity from 1985 to 1995 and from 1995 to 2005 (Figure 3), in a historical context, can be understood in the face of the agricultural activity expansion, with the coffee crop in the State of Rio de Janeiro, as well as logging, extending later to the study region, and aggravating degradation (Projeto Radambrasil, 1983). In addition, according to the Projeto Radambrasil (1983), with the decline of coffee plantations, areas formerly occupied by monoculture were converted to extensive cattle farming, planted with forage grasses. Moreover, with the decline of livestock activity, they later began to be used for urban expansion.

Real estate speculation is another fundamental aspect in the municipality of Resende, deserving to be in this discussion. For Magalhães (2017), in the 1990s, changes in the productive

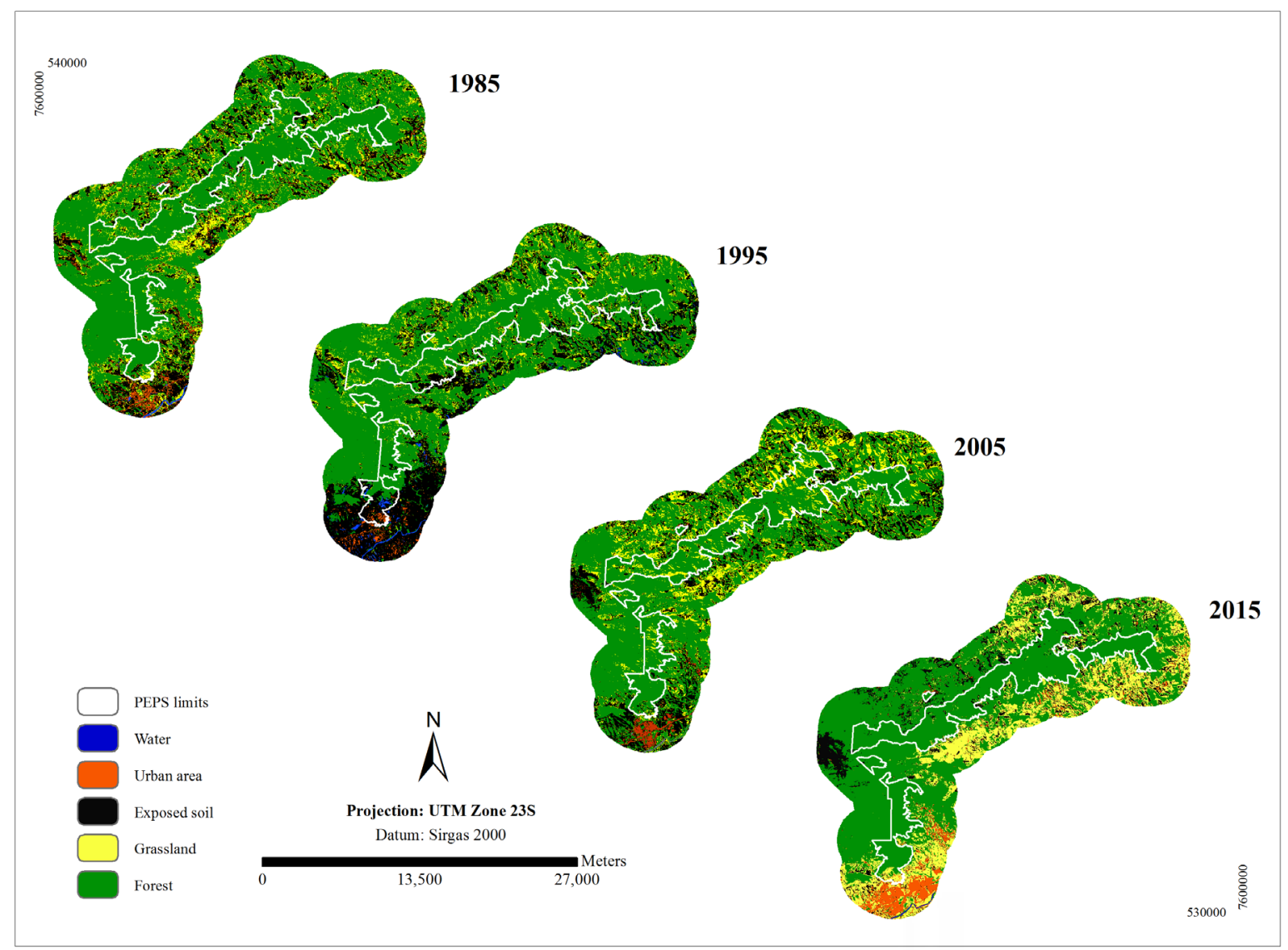

Figure 3. Dynamics of land-use and land cover in the Parque Estadual da Pedra Selada and Buffer Zone (BZ), RJ, Brazil. 
sphere at a global, national and regional scale caused significant influences in the space production of Resende, as it began to receive an expressive set of industries related to the metal manufacturing under new productive and spatial arrangements. The same author also explains that due to them being known for their natural heritage, these areas also started to generate interest with the urban growth, attracting new visitors and real estate constructions.

According to the data available in the implementation of the Management Plan from Parque Estadual da Pedra Selada (Detzel et al. 2017), the general characteristics of this $\mathrm{CU}$ differ from one place to another, both in the Park and in its surroundings (BZ). Due to its status of main urban area around the Park, the human activities mainly occurred from the municipality of Penedo and led to deforestation throughout the year. For Detzel et al. (2018), advancement of households to previously vegetated areas have led to suppression over time, and consequently, it advanced to the PEPS limits. The same authors corroborate that changes in these spaces can bring problems, especially with the needy population, who coerced to leave their homes, end up opening new fronts of occupation.

The State of Rio de Janeiro does not have specific legislation on dealing with the buffers zone and on Conservation Units, regarding their use and restrictions. In Rio de Janeiro, the inexistence of rules regulating use activities in the buffer zone of protected areas can also cause difficulties in the application of the standard as well as in its demand (Costa et al., 2013). This lack of specification and use of the term buffer zone should be reviewed since Rio de Janeiro is the State that holds the highest percentage of remnants of the Atlantic Forest.

It is also important to note that the use of the buffer zone from Parque Estadual da Pedra Selada, whenever possible, should be carried out through traditional practices, local community lifestyles, and sustainable management of natural resources, and of course, with the effective action of the legislation and supervision of the responsible entities and management of the Park. This way, it can minimize environmental problems and ensure conservation of the biodiversity still contained in the Parque Estadual da Pedra Selada and other forest remnants present in its damping zone.

\section{Conclusions}

The spatial-temporal analysis of the landscape in PEPS was able to identify changes in the distribution of land-uses and covers over time. Before the creation of PEPS, there was a significant increase in exposed soil and grassland. After delimitation of PEPS, the grassland continued growing only in the buffer zone, while inside the PEPS these areas decreased.

In general, the main threats that interfere in the conservation of the PEPS and its surroundings is the anthropic pressure. Activities as tourism, real estate speculation, and agriculture may drive the fragmentation process and, therefore, may affect the diversity of flora and fauna present in the PEPS.

Anthropic activity intensified since the 90s, marking the dynamics of the landscape where the Parque Estadual da Pedra Selada is. Concerning that, the anthropic actions should deserve special and adequate treatment, linking the restructuring of the landscape with urban growth.

\section{Literature Cited}

Ahmad, C.B.; Jamalunlaili, A.; Jasmee, J. Community Perspectives on Buffer Zone for Protected Areas: A preliminary study. Procedia - Social and Behavioral Sciences, v.85, p.198-205, 2013. https:// doi.org/10.1016/j.sbspro.2013.08.351

Barreto, C. G.; Campos, J. B.; Roberto, D. M.; Roberto, D. M.; Teixeira, N.; Alves, G. S. G.; Coelho, W. Plano de manejo - Parque Nacional do Itatiaia. Brasília: ICMBIO, 2013. http://www.icmbio.gov.br/ portal/component/content/article?id=2181: parna-do-itatiaia. 29 Mar. 2019.

Bastiaanssen, W.G.M. Regionalization of surface flux densities and moisture indicators in composite terrain. Wageningen: Wageningen Agricultural University, 1995. 273p. Thesis PhD. http://edepot.wur.nl/206553. 01 Apr. 2019.

Brasil. Lei № 9985, de julho de 2000. Regulamenta o art. 225, § 10, incisos I, II, III e VII da Constituição Federal, institui o Sistema Nacional de Unidades de Conservação da Natureza e dá outras providências. Diário Oficial da União, v.138, n.138, seção 1 , p.45-48, 2000. http://pesquisa.in.gov.br/imprensa/jsp/visualiza/ index.jsp?data $=19 / 07 / 2000 \&$ jornal=1\&pagina $=45 \&$ totalArquiv os=58. 10 Jan. 2019.

Carvalho, D. C.; Pessoa, M. M. L.; Pereira, Marcos G.; Delgado, Rafael C. Evolution of cerrado vegetal cover on a river island based on orbital imaging data. Engenharia Agricola, v. 36, n. 6, p. 11861197, 2016. https://doi.org/10.1590/1809-4430.

Chander, G., Markham, B.; Barsi, J.A. Revised Landsat-5 thematic mapper radiometric calibration. IEEE Geoscience and Remote Sensing Letters, v. 4, n. 3, p.490-494, 2007. https://doi. org/10.1109/LGRS.2007.898285.

Costa, D.R.T.R.; Botezelli, L.; Silva, B.G.; Farias, O.L.M. Zonas de amortecimento em unidades de conservação: levantamento legal e comparativo das normas nos estados de Minas Gerais, Rio de Janeiro e São Paulo. Desenvolvimento e Meio Ambiente, v. 27 , p. $57-70,2013$. https://revistas.ufpr.br/made/article/ view/28036/20671. 22 Mar. 2019.

Crouzeilles R.; Lorini, M.L.; Viveiros, C.E. Grelle. The importance of using sustainable use protected areas for functional connectivity. Biological Conservation, v. 159, p. 450-457, 2013. https://doi. org/10.1016/j.biocon.2012.10.023.

Dalla Nora, E.L.; Santos, L. E. Dinâmica ambiental da zona de amortecimento de áreas naturais protegidas. Revista Ambiência. v.7, n.2, p. 279-293, 2011. https://doi.org/10.5777/ ambiencia.2011.02.06.

Defries, R.; Hansen, A.; Newton, A.C.; Hansen, M.C. Increasing isolation of protected areas in tropical forests over the past twenty years. Ecological Applications, v. 15, n.1, p.19-26, 2005. https://doi.org/10.1890/03-5258.

Detzel, V. A.; Baldim, M. M.; Cit, C.; Lamberti, S. P. Instituto Chico Mendes de Conservação da Biodiversidade - ICMBIO. Plano de manejo da Área de Proteção Ambiental da Serra da Mantiqueira. Brasília: Detzel Consultores Associados S/S EPP, 2018. 371 p. http:// www.icmbio.gov.br/portal/images/stories/plano-de-manejo/ plano_de_manejo_serra_da_mantiqueira_2018.pdf. 03 Apr. 2019. 
Detzel, V. A.; Baldim, M. M.; Cit, C.; Lamberti, S. P. Instituto do Meio Ambiente do Rio de Janeiro. Ações prioritárias para implementação do Parque Estadual da Pedra Selada. Diagnóstico da Unidade de Conservação. v.1. Rio de Janeiro: Detzel Consultores Associados S/S EPP, 2017.

Esri. ArcGIS Desktop 9.3 Help. Average nearest neighbor (spatial statistics). 2009. http://webhelp.esri.com/ arcgisdesktop/9.3/index.cfm?TopicName=Average_Nearest_ Neighbor_\%28Spatial_Statistics\%29. 22 Oct. 2018.

Ferraz, S.F.B.; Ferraz, K.M.P.M.B.; Cassiano, C.C.; Brancalion, P.H.S.; Luz, D. T.A.; Azevedo, T.N.; Tambosi, L.R.; Metzger, J.P. How good are tropical forest patches for ecosystem services provisioning? Landscape Ecology, v. 29, n.2, p.187-200, 2014. https://doi. org/10.1007/s10980-014-9988-z.

Franco, J. B. S.; Rosa, R. Análise da possibilidade de identificar pastagens degradadas utilizando dados radiométricos de campo. Sociedade \& Natureza, v. 16, n. 31, p. 37-55, 2004. http://www.seer.ufu.br/index.php/sociedadenatureza/article/ view/9191/5655. 10 Apr. 2019.

Hansen, M. C.; Loveland, T. R. A review of large area monitoring of land cover change using Landsat data. Remote Sensing of Environment, v. 122, p.66-74, 2012. https://doi.org/10.1016/j. rse.2011.08.024.

Instituto Brasileiro de Geografia e Estatística - IBGE. Manual técnico de uso da terra. 3.ed. Brasília: IBGE, 2013. 171p. (IBGE. Manuais técnicos em Geociências, 7). https://biblioteca.ibge.gov.br/ visualizacao/livros/liv81615.pdf. 01 Apr. 2019.

Lima, G. C.; Silva, M. L. N.; Curi, N.; Silva, M. A.; Oliveira, A. H.; Avanzi, J. C.; Ummus, M. E. Avaliação da cobertura vegetal pelo índice de vegetação por diferença normalizada (IVDN). Revista Ambiente \& Água, v. 8, n. 2, p. 204-214, 2013. https://doi.org/10.4136/ambiagua.959.

Magalhães, L. M. S. A. Reestruturação urbana em Resende-RJ e a autossegregação socioespacial. Espaço Aberto, v. 7, n.2, p.79-97, 2017. https://doi.org/10.36403/espacoaberto.2017.16315.

Maranhão, D. D. C.; Pereira, M. G.; Costa, E. M.; Anjos, L. H. C. Correção de imagens e caracterização do uso da terra no município de Pinheiral, estado do Rio de Janeiro, Brasil. Caminhos de Geografia, v. 18, n. 62 , p. 174-188, 2017. http://www.seer.ufu.br/index.php/ caminhosdegeografia/article/view/36893/20587. 29 Mar. 2019.

Moraes, M.C.P.; Mello, K.; Toppa, R. H. Protected areas and agricultural expansion: Biodiversity conservation versus economic growth in the Southeast of Brazil. Journal of Environmental Management. v.188, p. 73-84, 2017. https://doi.org/10.1016/j. jenvman.2016.11.075.

Nguyen, T.H.; Cook, M.; Field, J.L.; Khuc, Q.V.; Paustian, K. Highresolution trade-off analysis and optimization of ecosystem services and disservices in agricultural landscapes. Environmental Modelling \& Software, v. 107, p.105-118, 2018. https://doi. org/10.1016/j.envsoft.2018.06.006.
Projeto Radambrasil. Folhas 23/24, Rio de Janeiro/Vitória: geologia, geomorfologia, pedologia, vegetação, uso potencial da terra. Rio de Janeiro: Projeto Radambrasil, 1983. 775p. (Projeto Radambrasil. Levantamento de Recursos Naturais, 32). https:// biblioteca.ibge.gov.br/index.php/biblioteca-catalogo?view=deta Ihes\&id=217129. 22 Jan. 2019.

QGIS Development Team. QGIS. A free and open source geographic information system. Version 2.18, 2018. URL: https://www.qgis. org/en/site. 10 Jan. 2019.

Rio de Janeiro. Decreto № 43.640, de 15 de junho de 2012. Cria o Parque Estadual da Pedra Selada e dá outras providências. Diário Oficial do Estado do Rio de Janeiro, v.38, n.111, parte 1, p.1-3, 2012. http://www.pesquisaatosdoexecutivo.rj.gov.br/Home/ Detalhe/86073. 18 Jan. 2019.

Robinson, E.; Albers, H.J.; Busby, G.M. The impact of buffer zone size and management on illegal extraction, park protection and enforcement. Ecological Economics, v. 92. p. 96-103, 2013. https://doi.org/10.1016/j.ecolecon.2012.06.019.

Rosa, P. A.; Breunig, F. M.; Almeida, C. M.; Balbinot, R. Dinâmica de Fragmentos Florestais no Noroeste do Rio Grande do Sul. Geografia, Ensino \& Pesquisa, v. 21, n.1, p. 177-189, 2017. https://doi.org/10.5902/2236499424059.

Rouse, J.W.; Haas, R.H.; Schell, J.A.; Deering, D.W. Monitoring vegetation systems in the great plains with ERTS. In: Third Earth Resources Technology Satellite-1 Symposium, 1973, Washington. Proceedings... Washington: NASA, 2006. v.1: Technical Presentations, section A, p.309-317. https://ntrs.nasa.gov/ archive/nasa/casi.ntrs.nasa.gov/19740022614.pdf. 17 Feb. 2019.

Silva, A. C. P.; Freitas, M.M.; Fortuna, D.S. Zoneamento ecológico econômico de Resende (RJ). Rio de Janeiro: GeTERJ-NAT-PUCRio, 2010.69p

Souza, N.L.; De Angelis, B.D. Parque Municipal Cinturão Verde de Cianorte - Módulo Mandhuy e os principais impactos da área de entorno. Revista GEOMAE, v.2, n. 1, p.51-70, 2011. http://www. fecilcam.br/revista/index.php/geomae/article/viewFile/143/ pdf_27. 07 Feb. 2019.

Torres, F. N.; Richter, R.; Vohland, M. A multisensoral approach for high-resolution land cover and pasture degradation mapping in the humid tropics: A case study of the fragmented landscape of Rio de Janeiro. International Journal of Applied Earth Observation and Geoinformation, v. 78, p. 189-201, 2019. https://doi. org/10.1016/j.jag.2019.01.011.

Watson, F.; Matthew, S.; Becker, R.; McRobb, B. K. Spatial patterns of wire-snare poaching: Implications for community conservation in buffer zones around National Parks. Biological Conservation, v. 168, p. 1-9, 2013. https://doi.org/10.1016/j.biocon.2013.09.003. 